там, усередині їх, ще не прочахло тепло, ще тліє людське життя» [6, с. 156].

Міфологічний просторовий образ у романістиці Панаса Мирного являє собою особливий тип ментального простору і здійснюється крізь призми світовідчуття героїв. Такий вид простору вплітається в соціально-побутову сферу.

Художній світ романістики Панаса Мирного $є$ складною концептуально обгрунтованою структурою, де одна 3 детермінуючих ролей належить простору і часу.

\title{
Література:
}

1. Абасов. А. Пространство и время, пространственно-временная организация. Вопросы философии. 1985. № 11. С. 71-81.

2. Федоров, Ф. Романтический художественный мир: пространство и время. Рига: Зинатне. 1988. 567 с.

3. Гак В. Пространство вне пространства. Логический анализ языка. Языки пространств. Москва: Языки русской культуры, 2000. С. 127-134.

4. Бахтин, М.М. Эпос и роман (о методологии исследования романа). Вопросы литературы. 1970. № 1. С. 104.

5. Панас Мирний та Іван Білик. Хіба ревуть воли, як ясла повні? Київ : Радянський письменник, 1967. 333 с.

6. Мирний Панас. Твори в двох томах. Т. 2. Київ : Наук. думка, 1989. $634 \mathrm{c}$

DOI https://doi.org/10.30525/978-9934-26-073-5-1-44

\section{КОЛОРИСТИКА У БОРИСЛАВСЬКИХ ТВОРАХ ІВАНА ФРАНКА I СТЕФАНА КОВАЛІВА}

\author{
Шостак О. О. \\ кандидат філологічних наук, \\ методист навчально-методичного відділу \\ Рівненського державного гуманітарного університету \\ м. Рівне, Україна
}

У 1850-х рр. розпочалась індустріалізація Східної Галичини, пов'язана з видобуванням нафти. Основним промисловим центром став Борислав із сусідніми селами (Мразниця, Тустановичі, Східниця, Волянка). Травматичний процес руїни традиційного селянського побуту 
й формування нової робітничої ідентичності знайшов художнє відображення у творчості I. Франка, а також його послідовника С. Коваліва, тексти якого довгий час перебували поза увагою літературознавців. І. Франко відвідував С. Коваліва в Бориславі, обговорював із ним проблему галицької «нафтової лихоманки». I. Франко був ознайомлений з оповіданнями С. Коваліва про Борислав і попросив його як очевидця подій написати відповідну статтю до «Літературно-наукового вісника». У 1913 р. студію С. Коваліва «Продукція нафти (скального олію) в Бориславі» 3 Франковими коментарями опублікували в згаданому виданні. Бориславські твори I. Франка i C. Коваліва подібні за мотивним спектром, образами, особливостями поетики. Зокрема, мета наукової розвідки - з'ясувати художню функцію колористики у вказаних текстах.

Насамперед зазначимо, що заробітчанство на теренах так званої Галицької Каліфорнії розглядаємо в площині внутрішньої трудової міграції, а, отже, творчість про Борислав - як невід'ємний складник «еміграційного» тексту. У межах Франкової творчості «еміграційний» текст трактуємо як персональну надтекстову єдність, що «складається зі спільних за семантикою і художнім кодом творів, що розкривають тему еміграції та об'єднані центральними просторовими топосами батьківщини і чужини, переведеними в сакральний регістр образної антитези раю / пекла» (поема «Швінделеса Пархенбліта вандрівка з села Дерихлопи до Америки і назад», начерк драми «До Бразилії», поетичний цикл «До Бразилії!» та ін.) [4, с. 91]. На нашу думку, можна аналізувати й «еміграційний» текст української літератури загалом, якому властиві традиційна топіка (стійкі образи і мотиви: батьківщина-рай, чужинапекло, емігрант, агент, дорога) й особливий художній код загалом.

$\mathrm{У}$ творах на тему еміграції чітко окреслено топоси батьківщини й чужини, що корелюють із біблійними образами раю та пекла i виступають знаковими маркерами міграційної теми. Антитеза цих топосів у бориславському циклі І. Франка і С. Коваліва простежується й на рівні промовистої кольорової гами, що оприявнена передусім у пейзажних картинах, а також і в портретах персонажів. Особливо майстерно автори змалювали образ Борислава як пекла, містичного царства Задухи. Так, у вступному слові до збірки «Борислав. Картини 3 життя підгірського народу» I. Франко моделює алегоричний образ містапотвори, де панували злочинність і розпуста: «Борислав висисає вздовж і вшир всі сусідні села, - пожирає молоде покоління, ліси, час, здоров'я і моральність цілих громад, цілих мас» [3, т. 14, с. 276]. Обидва письменники вдаються й до безпосередніх означень Борислава як пекла: 
«Тадже ж я б не пішов був у тото пекло, коли б не нужда та не потріб» (I. Франко «На роботі») [3, т. 14, с. 300]; «[...] прийшов я перший раз до того пекла [...]» (С. Ковалів «Пригісник з Борислава») [2, с. 485]. Образ чужини-пекла увиразнюють індустріальні пейзажі $з$ домінантою чорного, сірого й червоного кольорів, які задають фатальну, тривожну тональність. Для селян краєвиди промислового міста були травматичним фактором: «Ясне, погідне небо горіло над гарячим Бориславом і виглядало так само сіро, як ціла зруйнована околиця. Вітер ні разу не шевельнув воздухом, не повінув холодом, не розсіяв важкого, густого сопуху, що, виходячи $з$ ям, з глини, з потоків, з брудних магазинів, залягав хмарою над Бориславом, спирав дух в груді» (І. Франко «Воа constrictor») $[3$, т. 14 , с. 407-408]. Депресивний пейзаж синестезійно інкрустовано алітерацією вібрантів. Антитеза села і міста як раю і пекла, незайманої природи й цивілізації простежується в невласне прямій мові Івана 3 Франкового оповідання «Ріпник» і психологічно проєктує внутрішній стан персонажа: «I вічно той смрід, той бруд, та духота, та пиятика, той одур! [...] Йому пригадалися зелені ниви, цвітисті луги, сиві воли, чисто побілені хатки і розкішні садки його рідного села [...] Невже він міг так легкодушно проміняти такий рай на отсе пекло?» [3, т. 21, с. 46]. С. Ковалів до натуралістичних пейзажів Галицької Каліфорнії майстерно додає імпресіоністичні настроєві елементи. Наприклад, влучно ретранслює драматизм червоний колір в оповіданні «Зваричі»: «А тут ще й фабрики з червоними дахами, немов кров'ю мужицькою помащені, покрашені [...]» [2, с. 217].

В індустріальних картинах бориславських творів I. Франка й С. Коваліва 3 чорною та сірою барвою асоціюється образ болота, що символізує чужину, безгрунтя, втрату моральних орієнтирів, смерть i належить до стійких топосів «еміграційного» тексту: «[...] у Бориславі на всіх вуличках було глибоке грузьке болото» (І. Франко «Слимак») $[3$, т. 15, с. 223]; «[...] трібували позбутись болота, в якім ноги, як угіпсовані, по коліна тяжіли» (С. Ковалів «Пригісник з Борислава») $[2$, c. 482$]$.

Текстам про роботу в Бориславі характерний танатологічний хронотоп, насамперед утілений в образі ями як місця загибелі. Топос ями корелює 3 могилою, гробом (чорним кольором), а опускання робітника під землю нагадує поховальний обряд: «Всім якось важко, немов при похороні, коли спускають трумну до гробу» (I. Франко «Воа constrictor») $[3$, т. 14, с. 412$]$; «Всюди ями непонакривані, необгороджені, отверті гроби, в котрих не одного сердягу, що вертав із роботи на спочинок [...], смерть несподівано постигла» (С. Ковалів «Добрий заробок») [2, с. 64]. 
Специфічна колористика притаманна й портретуванню бориславських робітників. Бруд маркує їх побут. Письменники змальовують обряд ініціації в ріпники, що відбувалась через вимазування кип'ячкою: «[...] треба тебе охрестити, небоже!» - «І сорочка біла, і руки, і волосє, всьо, всьо, мов 3 комина виняв» (І. Франко «На роботі») [3, т. 14, с. 294295]; «Кождого хлопа в поряднішій гуні брали жидівські невільниці поміж себе й клали на силу у найбільше болото при відголосі пекельних сміхів та віватів» (С. Ковалів «Добрий заробок») [2, с. 44]. Виписуючи колективний образ робітників в оповіданні «Андрій Кременяк», С. Ковалів означує яскравими художніми деталями їхній одяг та обличчя, що вказують на тяжку, каторжну працю: «Вчера сїм вертало: голі, босі, простоволосі і обчуджені чорною мазею, мов із трястя якого повилазили»; «Лиця глиняної краски, очи від замороки повипікані, червоні, мов кров, а в грудях кожному грає ріжним хрипучим гранєм» [зберігаю правопис видання. - О. Ш.; 1, с. 28, 50].

Бруд проникає і у внутрішній світ робітників-мігрантів, які цілковито змінюють ідентичність. У повісті І. Франка «Воа constrictor» закцентовано увагу не лише на одязі, а на голосі й погляді ріпників, що засвідчує прояв тваринних інстинктів, переродження у звіра (при цьому актуалізовано орнітологічний образ ворона - за міфологічними уявленнями, вісника смерті, горя): «Зачорнені скрізь нафтою та глиною, мов ворони, - на них пошарпані шмати - не то шкіра, не то якесь невидане полотно, - від них на сто кроків віє незносний дух нечистоти, сопуху, шинків, зопсуття! I голоси у них - ні, се не людські голоси, а якийсь крик глухий, хриплий, немов дренькіт розбитого баняка. А який позір у тих людей - дикий, зловіщий!» [3, т. 14, с. 370].

Топос міста-пекла репрезентують танатологічні мотиви й образи 3 відповідною кольоровою палітрою. Так, у традиціях натуралізму I. Франко відтворює епізод підняття з ями останків Івана Півторака: «3 темної пропасті виринала-виходила вгору на світло страшна, почорніла труп'яча голова. Герман [...] бачив виразно нелюдський злобний усміх на тих щербатих щоках, у тих огромних глиняних очах» («Boa constrictor») [3, т. 14, с. 416]. Письменник також завдяки вдалому нюансуванню барв малює обличчя вбивці до і після скоєння злочину, i таким чином відображає його кризовий екзистенційний стан: «Тільки Прийдеволя стояв коло порога 3 лицем мертвецьки блідим і з заломаними руками, стояв, як живий образ болю $[\ldots] » ; ~ «[\ldots]$ молодий парубок [...] поблід ще дужче, далі почервонів, а вкінці, тремтячи всім тілом, немов у зимниці, залився голосним плачем [...]»; «Його молоде лице було якесь бліде і мов зіссане, косим поглядом він позирав довкола 
і все мимоволі держався в темнім куті близ порога» («Борислав сміється») [3, т. 15, с. 325, 326, 373]. Примітно, що носій танатосу асоціюється і з білим, позаяк, за народними традиціями, смерть часто уявляли як жінку в білому одязі.

Отже, бориславські твори І. Франка і С. Коваліва мають особливу колористику, що слугує конструюванню еміграційного топосу чужинипекла, співвіднесеного 3 містом Бориславом. У пейзажних картинах $\mathrm{i}$ портретах персонажів превалюють чорний, сірий і червоний кольори, до яких іноді додано білий. Ці барви передають психологізм образів, забезпечують мінорну настроєву тональність текстів, підсилюють драматизм та увиразнюють танатологічний хронотоп.

\section{Література:}

1. Ковалів С. Похресник і інші оповідання. Львів: 3 друкарні Наукового товариства імени Шевченка під зарядом К. Беднарського, 1909. $195 \mathrm{c}$.

2. Ковалів С. Твори. Київ: Державне видавництво художньої літератури, 1958. $722 \mathrm{c}$.

3. Франко I. Зібрання творів. У 50 т. АН УРСР. Ін-т л-ри iм. Т. Г. Шевченка; редкол. : С.П. Кирилюк [голова] та ін. Київ : Наукова думка, 1976-1986.

4. Шостак О. О. «Еміграційний» текст Івана Франка : монографія. Рівне : «Волинські обереги», 2019. 288 с. 